\title{
MEDICINE AND HEALTH CARE
}

\section{Морфологічна характеристика ланок гемомікроциркуляторного русла за умов тривалого впливу опіоїду в експерименті}

\author{
Н. І. Гресько
}

Львівський національний медичний університет імені Данила Галицького

Paper received 27.06.18; Accepted for publication 01.07.18.

\section{https://doi.org/10.31174/SEND-NT2018-172VI20-09}

Анотація. Дослідження стосується хронічного впливу опіоїду на стан ангіоархітектоніки стінки ободової кишки. Експериментальне дослідження проведено на 24 білих щурах-самцях, яким протягом 6-ти тижнів щоденно внутрішньом'язово вводили налбуфін в наростаючих дозах. Контролем були 9 білих щурів, яким вводили 0,9 \% розчин хлориду натрію. Результати експериментального дослідження свідчать, що хронічний вплив опіоїду зумовлює значні дистрофічні зміни структурних компонентів гемомікроциркуляторного русла стінки ободової кишки.

Ключові слова: гемомікрочиркуляторне русло, ободова кишка, опіӧ̈д, ін'єкція, експеримент.

Вступ. У структурі загальної захворюваності населення одне $з$ провідних місць займають органи травлення, які є одними 3 найбільш поширених у світі та здатні ускладнювати й обтяжувати перебіг інших хвороб $[1,8]$. Серед причин, які сприяють цьому є не лише складна екологічна ситуація та різні захворювання, а й широке використання наркотичних середників у клінічній практиці з метою отримання знеболювального та протизапального ефектів [11, 12, 13, 17]. У силі знеболювальної дії з опіоїдними анальгетиками можуть конкурувати небагато лікарських засобів і перспективність їх використання неможливо недооцінювати [16]. Проте, постійне використання анальгетиків опіоїдного ряду приводить не лише до поведінкових змін, що проявляється параноїдальними психозами, а й спостерігається структурна дезорганізація органів [2, 9, 14]. Тому, закономірною $є$ зміна структури судин та їх функцій при патологічних умовах, що розглядається, як відповідь усіх складових іiі стінки (ендотеліоцитів, гладких міоцитів, сполучнотканинних елементів, тощо) на негативні фактори [10, $15]$.

Короткий огляд публікацій: закономірності ремоделювання судин вивчено за впливу опіоїду на мозочок, підшлункову залозу, судинну оболонку ока, міокард [3, 5, 6, 7], проте, практично відсутні дослідження, присвячені компонентам гемомікроциркуляторного русла ободової кишки за умов застосування опіоїдів. Тому вивчення особливостей морфології мікросудин ободової кишки є актуальним і має практичне значення, як у медичному, так і в соціальному аспектах.

Мета роботи. Встановити особливості структури гемомікроциркуляторного русла ободової кишки за умов 6-тижневого введення опіоїду (налбуфіну) в експерименті.

Матеріали та методи. Дослідження виконані на 24 білих щурах-самцях репродуктивного віку, (3,0-4,5 місяців), масою тіла 180-220 г. Протягом 6 тижнів експериментальним тваринам щоденно внутрішньом'язово вводили налбуфін в наростаючих дозах: I тиждень - 8 мг/кг, II тиждень - 15 мг/кг, III тиждень 20 мг/кг, IV тиждень - 25 мг/кг, V тиждень - 30 мг/кг, VI тиждень -35 мг/кг [4]. Забір матеріалу проводили через 6 тижнів введення препарату. Контролем були 9 білих щурів, яким вводили $0,9 \%$ розчин хлориду натрію. Матеріал дослідження представлений препаратами ободової кишки щурів з ін'єкованим судинним руслом, гістопрепаратами та ультрамікроскопічними зрізами стінки ободової кишки експериментальних тварин.

При експериментальному дослідженні використовували метод ін'єкції судинного русла ободової кишки щура туш-желатиновою масою. Просвітлення зрізів препарату проводили в гліцерині з 96\% етиловим спиртом у співвідношенні 1:1 впродовж 3 діб, потім у чистому гліцерині. Для проведення морфометричного аналізу використовували такі кількісні критерії: діаметр мікросудин, артеріоло-венулярний коефіцієнт, щільність сітки обмінних судин, коефіцієнт трофічної активності тканини. Статистичне опрацювання показників морфометричного дослідження ангіоархітектоніки ободової кишки щура при 6-тижневому впливі налбуфіну проводили за допомогою пакетів прикладних комп'ютерних програм для варіаційно-статистичного аналізу «GraphPad InStat». Для гістологічного дослідження зрізи стінки ободової кишки фарбували гематоксиліном і еозином. Препарати вивчали за допомогою мікроскопа Leica DM 2500 та фотографували за допомогою камери Leica DFC 450 C при збільшеннях мікроскопа: x 200, х 400, х 1000 .

У ході роботи використовували метод електронномікроскопічного дослідження. Відразу після евтаназії тварини, здійснювали забір і стандартне проведення матеріалу для електронної мікроскопії. Ультратонкі зрізи виготовиляли на ультрамікротомі УЖТП-3 за допомогою скляних ножів. Вивчення і фотографування матеріалу проводили 3 допомогою мікроскопа УЕМВ-100 К при напрузі прискорення 75 кВ і збільшеннях на екрані мікроскопу х1000-8000.

Тварин утримували в умовах віварію Львівського національного медичного університету імені Данила Галицького, експерименти проведені у відповідності $з$ положенням Європейської конвенції щодо захисту хребетних тварин, яких використовують в експериментальних та інших наукових цілях (Страсбург,1986), Директиви Ради Свропи 86/609/EEC(1986 р.), Закону 
України № 3447 - IV «Про захист тварин від жорстокого поводження», загальних етичних принципів експериментів на тваринах, ухвалених Першим національним конгресомУкраїни з біоетики (2001р.).

Результати досліджень та їх обговорення.

Через 6 тижнів введення налбуфіну на ін'єкованих препаратах стінки ободової кишки експериментальних тварин спостерігаються глибокі деструктивні зміни гемомікроциркуляторного русла ободової кишки (рис. 1).

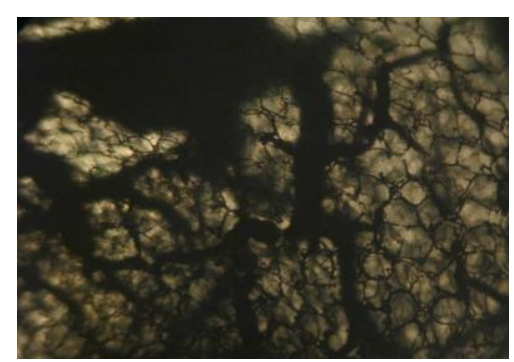

Рис. 1. Глибокі деструктивні зміни ланок гемомікроциркуляторного русла стінки ободової кишки білого щура через 6 тижнів введення налбуфіну. Мікрофотографія. Ін'єкція судин туш-желатиновою масою. Зб.: х160.

Капілярна сітка втрачає вигляд правильних багатогранників, часто обривається, оскільки руйнується капілярний компонент (рис.2).

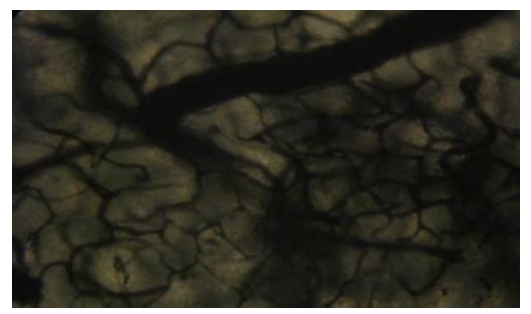

Рис. 2. Руйнування капілярної петлі стінки ободової кишки щура за умов 6-тижневого введення налбуфіну. Мікрофотографія. Ін'єкція судин туш-желатиновою масою. Зб.:х 320.

Спостерігається зменшення діаметру капілярної петлі, що становить $(3,51 \pm 0,24)$ мкм, контроль $(4,80 \pm 0,25)$ мкм. Діаметр артеріол на цьому терміні експерименту становить $(16,21 \pm 0,20)$ мкм, контроль - $(15,64 \pm 0,28)$ мкм. Зменшення їхнього діаметру в порівнянні 3 попередніми термінами експерименту зумовлене склерозуванням та потовщенням стінок артеріол. Розширюються артеріоло-венулярні анастомози і кров 3 артеріол скидається у венозне русло, минаючи зруйновані капіляри. Таким чином, закономірно, що застій та порушення відтоку венозної крові спричиняють розширення венулярного компоненту, що підтверджується значним зростанням діаметра венул до $(41,18 \pm 0,31)$ мкм, контроль - $(23,24 \pm 0,30)$ мкм. Відповідно артеріоло-венулярний коефіцієнт зменшується і становить $(0,39 \pm 0,01)$ мкм.

Спостерігається зміна щільності судин, порушення їх цілісності, що підтверджується наступними змінами морфометричних показників. Щільність сітки обмінних судин різко зменшується, що можна пояснити розвитком значної деструкції, переважно капілярів стінки ободової кишки, і становить $(15,80 \pm 1,04)$ мкм, контроль - $(21,55 \pm 1,45)$ мкм. Показник трофічної активності тканини збільшується до $(87,88 \pm 0,27)$ мкм, контроль - $(55,64 \pm 0,07)$ мкм.
Наявні виражені розлади гемодинаміки мікроциркуляторного русла ободової кишки підтверджує гістологічне дослідження. Просвіти кровоносних капілярів та венул в слизовій оболонці та підслизовому прошарку розширені та повнокровні. Навколо них виявляли набряк інтерстицію та виражену лейкоцитарну інфільтрацію. Артеріоли підслизової основи та м'язової оболонки стінки ободової кишки щурів, повнокровні, звужені в порівнянні з інтактними щурами. Ендотеліоцити в їх стінках не утворювали суцільний пласт. Спостерігали виражений набряк в підендотеліальному шарі внутрішньої оболонки артеріол, гіпертрофію та гіперплазію гладких міоцитів у середній оболонці артеріол (рис. 3).

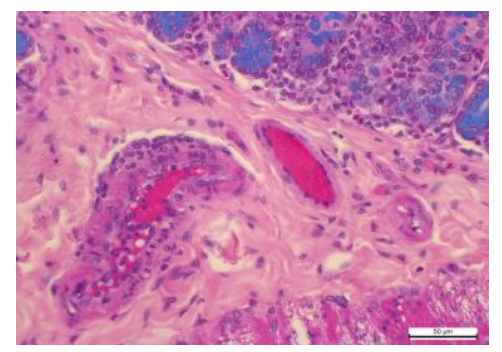

Рис. 3. Фрагмент слизової оболонки та підслизового прошарку стінки ободової кишки білого щура через 6 тижнів введення налбуфіну. Мікрофотографія. Забарвлення альциановим синім за Стідманом. 3б.: $\times 400$.

У серозній оболонці ободової кишки також мали місце інфільтрація, розширення просвітів та виражене повнокров'я судин кровоносного мікроциркулятрного русла, спостерігали периваскулярний набряк, та подекуди крововиливи навколо капілярів та венул. Окремі судини містили агреговані білкові маси плазми крові. Стінки окремих гіперемійованих судин просякали білками плазми крові та ставали інтенсивно ШИКпозитивними (рис. 4). Основна речовина сполучної тканини навколо них також нагромаджувала ШИКпозитивні речовини.

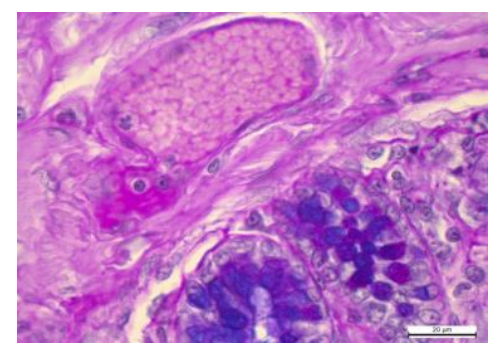

Рис. 4. Фрагмент слизової оболонки та підслизового прошарку стінки ободової кишки білого щура через 6 тижнів введення налбуфіну. Мікрофотографія. Забарвлення PASреакція $з$ дофарбуванням альциановим синім за Стідманом. 3б.: $\times 1000$.

Ультрамікроскопічне дослідження підтверджує виражені порушення гемодинаміки в судинах кровоносного мікроциркуляторного русла слизової оболонки ободової кишки у вигляді розширених просвітів та повнокров'я, адгезії та діапедезу лейкоцитів через їх стінки, а також значного навколосудинного набряку інтерстицію. У просвітах кровоносних капілярів виявляли скупчення еритроцитів та тромбоцитів, наявні лапаті маси. В ендотеліоцитах стінок кровоносних капілярів дистрофічні та деструктивні зміни органел, 
набряк цитоплазми. Відзначено, що в ядрах пошкоджених ендотеліоцитів, переважає гетерохроматин, вони неправильної форми, утворюють інвагінації їх ядерна оболонка пошкоджена (рис. 5). Інша частина ендотеліальних клітин, що прилягає до базальної мембрани, дезорганізована, цитоплазма наповнена преципітатами та коагулятами. Зауважено також, що люменальна поверхня ендотеліоцитів 3 нечіткими контурами, що зумовлено іiі випинами. У частині ендотеліоцитів наявні електроннощільні ядра в цитоплазмі яких розташовані чисельні вакуолі. Базальна мембрана навколо судин розпушена. Основна речовина в ній дезорганізована. Кровоносні судини заповнені скупченням еритроцитів та лімфоцитів, еритроцити розташовані у вигляді монетних стовпчиків.

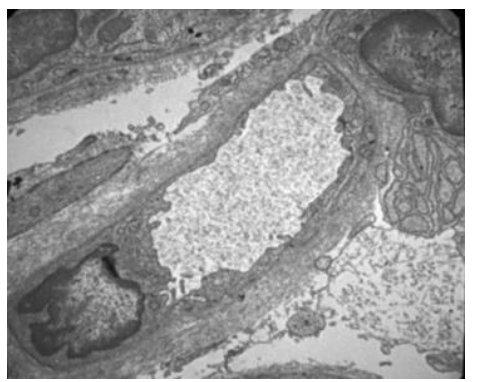

Рис. 5. Капіляр стінки ободової кишки білого щура через 6 тижнів введення налбуфіну. Електронна мікрофотографія. 3б.: $\times 4000$.

Стінка артеріол потовщена за рахунок набряку інтими а також гіпертрофії та гіперплазії гладких міоцитів в середній оболонці. Характерним є виражений набряк навколо артеріол. Просвіти венул розширені заповнені агрегатами еритроцитів, лейкоцитів. Посилені адгезія та діапедез лейкоцитів через стінки вену (рис. 6). Наявний набряк навколо судин та крововиливи.

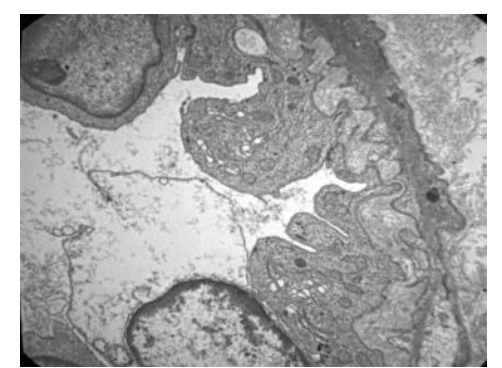

Рис. 6. Просвіт венули білого щура за умов 6-тижневого введення налбуфіну. Електронна мікрофотографія. Зб.: $\times 6000$.

Висновоки. Отже, макро-, мікро-, та електронномікроскопічне дослідження компонентів гемомікроциркуляторного русла слизової оболонки ободової кишки білого щура за умов 6-тижневого введення налбуфіну показали глибокі деструктивні зміни структури усіх ii складових. В мікросудинах виражене повнокрів'я, міграція лейкоцитів через їх стінки та крововиливи. Наявні периваскулярні запальні інфільтрати. Ультраструктурна реорганізація проявляється ендотеліальною дисфункцією судин, периваскулярним набряком та лейкоцитарною інфільтрацією. Спостерігається чіткий зв'язок між змінами ангіоархітектоніки на мікро- та ультрамікроскопічному рівнях i морфометричними показниками. Зменшення діаметру артеріол, щільності сітки обмінних судин, артеріоловенулярного коефіцієнта, розрідження капілярної сітки, розширення та деформація венул, а також збільшення показника трофічної активності свідчать про розвиток деструктивних змін ланок гемомікроциркуляторного русла.

\section{ЛІТЕРАТУРА}

1 Желєзнякова Н. М. Морфофункціональний стан слизової оболонки шлунка та дванадцятипалої кишки у хворих 3 пептичною дуоденальною виразкою в поєднанні з гіпертонічною хворобою. Український терапевтичний журнал. 2007;2:66-69.

2. Златковский В. В. Предиспозиційні чинники формування наркотичної залежності та принципи соціальнопсихологічної реабілітації хворих з залежністю від психоактивних речовин. Вісник Харківського національного університету імені ВН Каразіна. Серія: Психологія. 2012;50:207-209.

3. Матещук-Вацеба Л. Р., Бекесевич А. М. Структурна організація кори мозочка щура за умов 6-тижневого введення опіоїду. Клінічна анатомія та оперативна хірургія. 2015;14(2):68-71.

4. Пат. №76564 U Україна, МПК А 61 К 31/00 Спосіб моделювання фізичної опіоїдної залежності у щурів / заявники: Р.М. Онисько, С.В. Пальтов, В.Б. Фік, І.В. Вільхова Ю.Я. Кривко, Н.Я. Якимів, О.С. Фітькало; патентовласник: Львівський національний медичний університет імені Данила Галицького. - № u201207124; заявл. 12.06.2012; опубл. 10.01.2013 // Бюл. №1

5. Підвальна У.С. Структурні особливості судинної оболонки очного яблука за умов довготривалого опіоїдного впливу в експерименті. Актуальні проблеми сучасної медицини: Вісник Української медичної стоматологічної академії. 2014;14(4(48)):209-212.

6. Покотило В. Ю., Галюк У. М., Матешук-Вацеба Л. Р. Морфологічні особливості міокарда та його гемомікро-

циркуляторного русла на світлооптичному рівні за умов перебігу експериментальної опіоїдної інтоксикації. Вісник проблем біології і медицини. 2017;2(4):123128.

7. Попик П. М., Матещук-Вацеба Л. Р. Ультраструктурна організація ендокринної частини та гемомікроциркуляторного русла підшлункової залози за умов довготривалого впливу опіоїду в експерименті. Клінічна анатомія та оперативна хірургія. 2015;14(2):72-76.

8. Романюк Л. М., Федчишин Н. Є., Шостак С. Є. Основні закономірності та тенденції поширеності хвороб органів травлення. Вісник соціальної гігієни та організації охорони здоров'я України. 2013;1:49-52.

9. Фітькало О. С. Моніторинг поширеності розладів психіки та поведінки внаслідок вживання психоактивних речовин серед населення м. Львова та Львівської області. Медична освіта. 2013;3:105-108.

10. Katsanos A. H., Kosmidou M., Giannopoulos S., Katsanos K. H., Tsivgoulis G., Kyritsis A. P.et al. Cerebral arterial infarction in inflammatory bowel diseases. European journal of internal medicine. 2014;25(1):37-44.

11. Knight-Sepulveda, K., Kais, S., Santaolalla, R., Abreu, M. T. Diet and inflammatory bowel disease. Gastroenterology \& hepatology, 2015;11(8):511-520.

12. Molodecky N. A., Kaplan G. G. Environmental risk factors for inflammatory bowel disease. Gastroenterology \& hepatology. 2010;6(5):339-346. 
13. Ponder A., Long M. D A clinical review of recent findings in the epidemiology of inflammatory bowel disease. Clinical epidemiology. 2013. 5:237-247.

14. Sullivan M. D., Edlund M. J., Zhang L., Unützer J., Wells K. B. Association between mental health disorders, problem drug use, and regular prescription opioid use. Archives of internal medicine. 2006;166(19): 2087-2093.

15. Zanoli L., Rastelli S., Inserra G., Castellino P. Arterial structure and function in inflammatory bowel disease. World
Journal of Gastroenterology: WJG. 2015;21(40):1130411311.

16. Zielińska M., Ben Haddou T., Cami-Kobeci G., Sałaga M., Jarmuż A., Padysz M., Fichna J. Anti-inflammatory effect of dual nociceptin and opioid receptor agonist, BU08070, in experimental colitis in mice. European Journal of Pharmacology. 2015;765:582-590.

17. Zhang Y. Z., Li Y. Y. Inflammatory bowel disease: pathogenesis. World journal of gastroenterology: WJG.2014;20(1):91.

\section{REFERENCES}

1. Zheleznyakova N. M. Morphofunctional state of the mucous membrane of the stomach and duodenum in patients with peptic duodenal ulcer in combination with hypertension. Ukrainian Therapeutic Journal. 2007; 2: 66-69.

2. Zlatkovskii V.V. Forecasting factors of formation of narcotic dependence and principles of social-psychological rehabilitation of patients with dependence on psychoactive substances. Bulleten of Kharkiv National University named after V.N. Karazin. Series: Psychology. 2012; 50: 207-209.

3. Mateshuk-Vatseba L. R., Bekesevych A. M. Structural organization of rat cerebellar cortex under the influence of 6-week opioid administration. Clinical Anatomy and Operative Surgery. $2015 ; 14$ (2): 68-71.

4. Pat. №76564 U Ukraine, MPK A 61 K 31/00 Method of modelling of physical opioid dependence in rats / applicants: P.M. Onisco, Ye.V. Coats, V. B. Fick, I.V. Vilkhova, Yu.Ya. Kryvko, N.Ya. Yakimov, O. S. Phytcalo; patent holder: Danylo Halytsky Lviv National Medical University. - № u201207124; stated. 12.06.2012; has published 10/01/2013 // Byul. №1

5. Pidvalna U. Ye. Structural features of the vascular membrane of the eyeball under the long-term influence of opioid in the experiment. Actual problems of modern medicine: Bulleten of the Ukrainian Medical Stomatological Academy. 2014; 14 (4 (48)): 209-212.

6. Pokotylo V. Yu., Halyuk U. M., Mateshuk-Vatseba L. R. Morphological peculiarities of the myocardium and its hemomycrocycirculatory bed at the optical level under the conditions of the course of experimental opioid intoxication. Bulleten of Biology and Medicine. 2017; 2 (4): 123-128.

7. Popyk P. M., Mateshuk-Vatseba L. R. Ultrastructural organization of the hemomycocirculatory bed of the endocrine part of the pancreas under the long-term influence of the opiate in the experiment. Clinical Anatomy and Operative Surgery. 2015; 14 (2): 72-76.

8. Romanyuk L. M., Fedchyshyn N. E., Shostak S. Ye. Basic regularities and tendencies of the prevalence of diseases of the digestive system. Bulleten of Social Hygiene and Health Care Organizations of Ukraine. 2013; 1: 49-52.

9. Fytkalo O. S. Monitoring of the prevalence of mental and behavioral disorders due to the use of psychoactive substances amoung the population of Lviv and Lviv region. Medical education. 2013; 3: 105-108.

\section{Morphological characteristics of the parts of the hemomicrocirculatory bed under prolonged exposure of the opioid in the} experiment

\section{N. I. Hresko}

Abstract. Our study deals with chronic effect of the opioid on the angioarchitecture of the colon wall. These investigations were carried out on 24 mature white male rats. The animals were injected every day by opioid for 6 weeks and the dose was increased weekly. 9 white rats to which $0.9 \%$ sodium chloride was injected served as the control group. The results of the experimental study indicate that the chronic effect of the opioid causes significant dystrophic changes in the structural components of the hemomycocirculatory bed of the colon wall.

Keywords: hemomycocirculatory bed, colon, opioid, injection, experiment.

\footnotetext{
Морфологическая характеристика звеньев гемомикроциркуляторного русла при условии длительного воздействия опиоида в эксперименте

Н. И. Гресько

Аннотация. Исследование касается хронического воздействия опиоида на состояние ангиоархитектоники стенки ободочной кишки. Экспериментальное исследование проведено на 24 белых крысах-самцах репродуктивного возраста, которым в течение 6 недель ежедневно внутримышечно вводили налбуфин в нарастающих дозах. Контролем были 9 белых крыс, которым вводили $0,9 \%$ раствор хлорида натрия. Результаты экспериментального исследования свидетельствуют, что хроническое воздействие опиоида обусловливает значительные дистрофические изменения структурных компонентов гемомикроциркуляторного русла стенки ободочной кишки.
}

Ключевые слова: гемомикроциркуляторное русло, ободочная кишка, опиоид, инекция, эксперимент. 